Caballero-Ochoa, A.A., Buitrón-Sánchez, B.E., ConejerosVargas, C.A., Esteban-Vázquez, B.L., Ruiz-Nava, M.P., Jiménez-López, J.C., Solís-Marín, F.A., \& Laguarda-Figueras, A. (2021). Morphological variability of recent species of the order Cassiduloida (Echinodermata: Echinoidea) of Mexico. Revista de Biología Tropical, 69(S1), 423-437. DOI 10.15517/ rbt.v69iSuppl.1.46382

DOI 10.15517/rbt.v69iSuppl.1.46382

\title{
Morphological variability of recent species of the order Cassiduloida (Echinodermata: Echinoidea) of Mexico
}

\author{
Andrea Alejandra Caballero-Ochoa ${ }^{1,2 *}$ \\ Blanca E. Buitrón-Sánchez ${ }^{3}$ \\ Carlos A. Conejeros-Vargas ${ }^{4}$ \\ Brenda L. Esteban-Vázquez ${ }^{1}$ \\ Mariana P. Ruiz-Nava ${ }^{5}$ \\ José Carlos Jiménez-López ${ }^{6}$ \\ Francisco A. Solís-Marín ${ }^{7}$ \\ Alfredo Laguarda-Figueras ${ }^{7}$
}

1. Facultad de Ciencias, Universidad Nacional Autónoma de México. Circuito Exterior, C.P. 04510, Ciudad de México, México; a.caballero.ochoa@ciencias.unam.mx (*Correspondence), brenda.estebanv@gmail.com

2. Posgrado en Ciencias Biológicas, Universidad Nacional Autónoma de México, C.P. 04510, Ciudad de México, México.

3. Instituto de Geología, Departamento de Paleontología, Universidad Nacional Autónoma de México, Circuito Exterior, C.P. 04510, Ciudad de México, México; blancab@unam.mx

4. Posgrado en Ciencias del Mar y Limnología, Universidad Nacional Autónoma de México, C.P. 04510, Coyoacán, Ciudad de México, México; conejeros@ciencias.unam.mx

5. Facultad de Estudios Superiores Iztacala, Universidad Nacional Autónoma de México. Av. de Los Barrios 1, Tlalnepantla de Baz, C.P. 54090, Estado de México, México; mpaola.ruiznava@gmail.com

6. Posgrado en Ciencias de la Tierra, Instituto de Geología, Universidad Nacional Autónoma de México. Circuito Exterior, C.P. 04510, Ciudad de México, México; jcj11712@gmail.com

7. Colección Nacional de Equinodermos "Dra. Ma. Elena Caso Muñoz", Laboratorio de Sistemática y Ecología de Equinodermos, Instituto de Ciencias del Mar y Limnología, Universidad Nacional Autónoma de México, C.P. 04510, Ciudad de México, México; fasolis@cmarl.unam.mx, laguarda@cmarl.unam.mx

Received 15-VII-2020. Corrected 09-IX-2020. Accepted 15-XI-2020.

\begin{abstract}
Introduction: In Mexico, there are two recorded living species of Cassiduloida: Cassidulus caribaearum and Rhyncholampas pacifica. Most of the taxonomic studies on cassiduloids have used external morphology, pedicellariae and morphometric characters; however, the intraspecific variation of quantitative and qualitative characters has been poorly evaluated. Objective: To compare the basic morphology of $R$. pacifica and C. caribaearum. Methods: We examined a total of 2158 specimens of $R$. pacifica and $C$. caribaearum, selecting 50 to evaluate shape and size with linear regression and Principal Component analysis. We selected an additional 62 specimens per species to identify significant character correlations and morphological groups within species. Results: There is a direct relationship between Test length and Test width. Test height/Test width, and Total length (oral view)/Distance from the ambitus to the peristome apex, are the two main ratios to distinguish both species. C. caribaearum is more dorsoventrally compressed and has a round peristome base; versus $R$. pacifica has a tall and triangular one. There are four morphological groups of $C$. caribaearum and two groups for $R$. pacifica. Conclusions: These two species can be distinguished with reliable morphological characters, in which peristome shape suggests that $R$. pacifica is more adapted to burrowing deeper into certain types of substratum.
\end{abstract}

Key words: Neognathostomata; Cassiduloida; morphometry; Mexico. 
The order Cassiduloida (sensu Souto, Mooi, Martins, Menegola, \& Marshall, 2019) includes the families Cassidulidae, Eurhodiidae, Faujasiidae, Neolampadidae, and Pliolampadidae (Souto et al., 2019), is represented by 800 species, most of them fossils and a few living ones (Kier, 1962). One of the most characteristic aspects of these families is that their fossil record, and not the living representatives, contains most of their morphological diversity. Their variable morphology has made their taxonomic study complicated and possibly denotes that the group is in the process of extinction (Suter, 1988).

The cassiduloids first appeared and changed from infaunal to epifaunal habits during the Lower Jurassic (Boivin, Saucède, Laffont, Steimetz, \& Neige, 2018; Souto et al., 2019). They diversified in the Early Cretaceous and survived the K-Pg mass extinction, were common in the Late Cretaceous and Early Cenozoic, being more successful in the Eocene ( $>40 \%$ of the echinoid diversity), and finally have dramatically declined in number since then (Kier, 1962; Kier, 1974; Suter, 1988; McNamara, Pawson, Miskelly, \& Byrne, 2017). Kier (1962) noticed several morphological changes within the cassiduloids: abrupt reduction from two pores to one pore in each ambulacral plate beyond the petal and the introduction of buccal pores (Cenomanian), due to a radical change in the living habits (began to borrow shallowly into the substratum); and a change in the structure of the apical system from tetrabasal to monobasal (Maastrichtian), probably produced by parallel mutations and parallel selections. Recent studies have shown that their evolutionary history has been dominated by high levels of homoplasy and a dearth of unique, novel traits (Souto et al., 2019).

In Mexico, there exist two living species of cassiduloids: Cassidulus caribaearum and Rhyncholampas pacifica (Buitrón-Sánchez, Solís-Marín, Conejeros-Vargas, \& CaballeroOchoa, 2019). Cassidulus caribaearum inhabits warm, shallow waters $\left(26-28{ }^{\circ} \mathrm{C}\right)$, from less than 1 to $18 \mathrm{~m}$ in depth, buried up to 20 $\mathrm{cm}$ in calcareous sand $( \pm 2000-44 \mu \mathrm{m})$ or

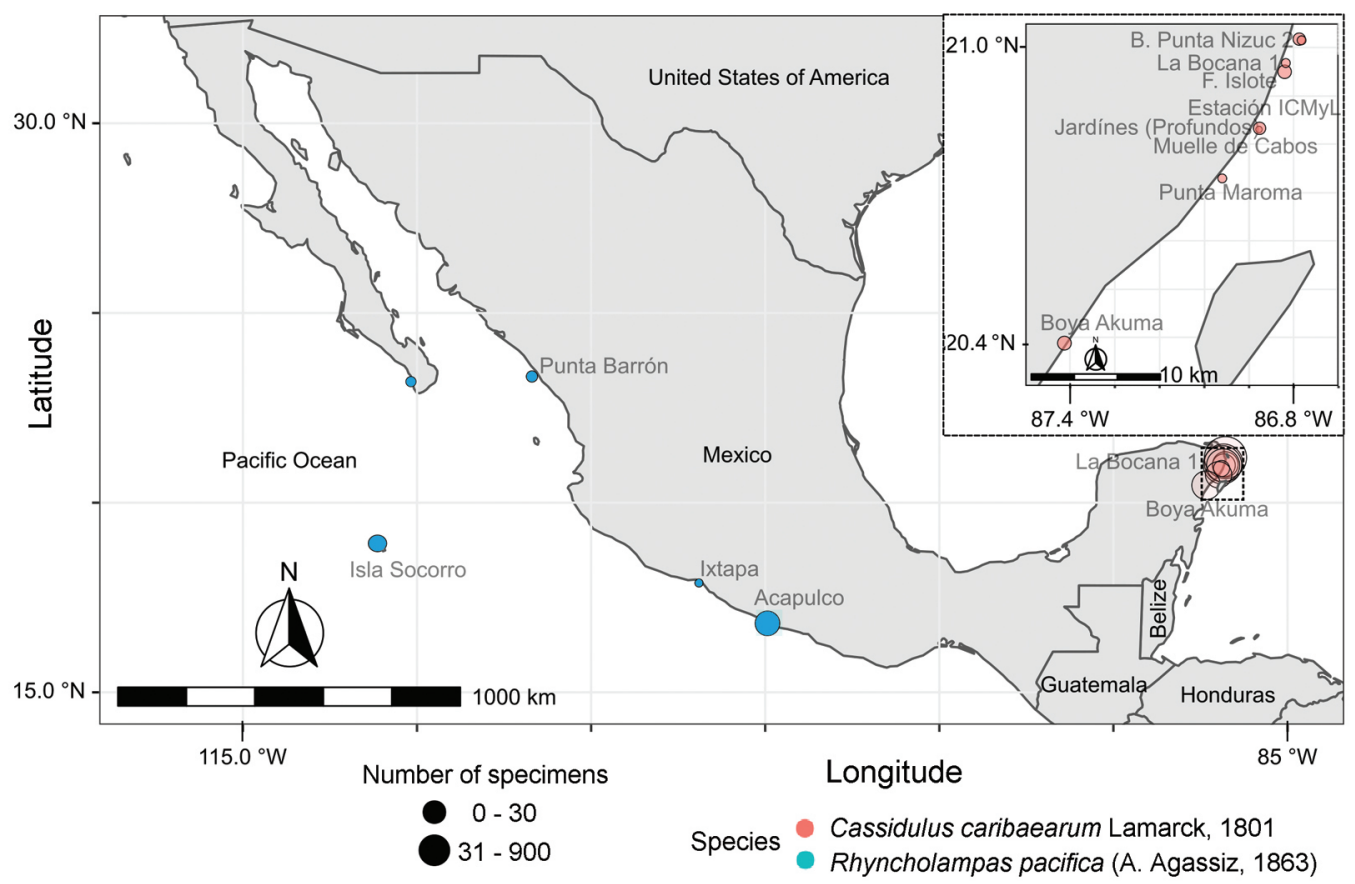

Fig 1. Distribution map of Cassidulus caribaearum and Rhyncholampas pacifica in Mexico. 
carbonate substratum of the tropical Atlantic West coast, and it is probably endemic to the Caribbean Sea (Fig. 1) (Kier, 1975; Gladfelter, 1978; Borrero-Pérez, Benavides-Serrato, \& Diaz-Sanchez, 2012; Solís-Marín et al., 2013; Solís-Marín, Caballero-Ochoa, Laguarda-Figueras, \& Durán-González, 2017; Souto \& Martins, 2018). Rhyncholampas pacifica lives in warm, shallow waters $\left(26-30^{\circ} \mathrm{C}\right)$ of the Tropical Eastern Pacific Ocean (Fig. 1). This species lives gregariously and partially buried to the level of the petaloids on sandy beaches at a depth of 2 to $130 \mathrm{~m}$ (Agassiz, 1872; Clark, 1925; Mooi, 1990; Solís-Marín et al., 2013; Caballero-Ochoa, Martínez-Melo, ConejerosVargas, Solís-Marín, \& Laguarda-Figueras, 2017; Schultz, 2017).

Morphometrics evaluates the size and shape variation of biological forms through statistical analysis (Ocakoglu \& Ercan, 2013). The traditional approach involves two-dimensional linear measurements such as lengths, widths and distances, and angles or ratios; it has been used in taxonomy since it is useful for making morphological comparisons and establishing specific boundaries, as well as assessing growth changes (Ocakoglu \& Ercan, 2013; Remagnino, Mayo, Wilkin, Cope, \& Kirkup, 2016; MacLeod, 2017). The application of morphometrics on cassiduloid taxonomy dates back to McKinney (1986), who discussed the heterochronic-ecological relationships between fossil irregular echinoids, including Rhyncholampas species. Although Carter and Beisel (1987) did not perform any statistical analysis, they also considered width/length ratios of the test for separating Eurhodia, Rhyncholampas and Cassidulus species. In addition, Ciampaglio and D’Orazio (2007) and Martínez-Melo (2008) provided insights into the growth trajectories and heterochronic processes between Eurhodia appendiculata, Rhyncholampas carolinensis and Eurhodia rugosa, and between C. caribaearum and R. pacifica, respectively. Recently, Martínez-Melo, De Luna and Buitrón-Sánchez (2017) evaluated the contours of the tests (lateral, aboral and posterior) of Cassidulidae species through geometric analyses, being the first study focused on this computational approach for cassiduloids.

The test shape is the most important characteristic to distinguish between species of cassiduloids (Souto et al., 2019). In most of the studies, the morphological diversity of the order Cassiduloida has been described (Souto et al., 2019); however, the intraspecific variation of the morphological characters of the recent cassiduloids in Mexico has not been evaluated. The objective of this work is to compare the basic morphological and morphometric aspects, as well as to evaluate the intraspecific variation of the morphometric characters of $R$. pacifica and C. caribaearum.

\section{MATERIALS AND METHODS}

Data collection: A total of 2158 specimens of recent cassiduloids were examined: $C$. caribaearum and R. pacifica; these are housed at Colección Nacional de Equinodermos "Dra. Ma. Elena Caso Muñoz" (ICML-UNAM) in Mexico (Appendix 1).

Morphometric analyses: We selected 50 specimens of different sizes of $C$. caribaearum and $R$. pacifica, from 3.3 to $51 \mathrm{~mm}$ in length; these were randomly selected and were photographed from the aboral, oral and lateral views. ImageJ software was used to obtain nine measurements for each specimen: TLa, TW, Da-ppa, TLo, Da-pta, THl, TWl, PpL, and PpW (Fig. 2, Table 1). A linear regression analysis was performed to test the relationship between the length and width of the test in GraphPad Prism. A Principal Component analysis using Primer-6 software was performed; five ratios were considered: 1) test length (aboral view)/ test width (at the level of the apical system), 2) test length (aboral view)/distance from the ambitus to the periproct apex, 3) test length (oral view)/distance from the ambitus to the peristome apex, 4) test height (lateral view)/test length (lateral view), and 5) periproct length/ periproct width. The data were transformed through square roots (Lawrence \& Cobb, 2017) (Table 1). 
TABLE 1

Abbreviations and definitions of measurements and ratios used in this study

\begin{tabular}{|c|c|}
\hline Abbreviation & Definition \\
\hline TLa & Test length (aboral view) \\
\hline TW & Test width (at the level of the apical system) \\
\hline Da-ppa & Distance from the ambitus to the periproct apex \\
\hline TLo & Test length (oral view) \\
\hline Da-pta & Distance from the ambitus to the peristome apex \\
\hline THl & Test height (lateral view) \\
\hline TWl & Test width (lateral view) \\
\hline $\mathrm{PpL}$ & Periproct length \\
\hline $\mathrm{PpW}$ & Periproct width \\
\hline A & Ambitus \\
\hline PW & Peristome width \\
\hline PL & Peristome length \\
\hline AIIIL & Third ambulacrum length \\
\hline AIL & First ambulacrum length \\
\hline MAW & Maximum width ambulacra \\
\hline PIW & Maximum width of the outer poriferous zone of petal I \\
\hline PB & Petaloid beginning $(\%)$ \\
\hline AFFP & Angle between the first and fifth petaloids $\left(^{\circ}\right)$ \\
\hline AFTP & Angle between the first and third petaloids $\left({ }^{\circ}\right)$ \\
\hline $\mathrm{TLa} / \mathrm{TW}$ & Test length (aboral view) / Test width (at the level of the apical system) \\
\hline TLa / Da-ppa & Test length (aboral view) / Distance from the ambitus to the periproct apex \\
\hline TLo / Da-pta & Test length (oral view) / Distance from the ambitus to the peristome apex \\
\hline TH1 / TW1 & Test height (lateral view) / Test width (lateral view) \\
\hline $\mathrm{PpL} / \mathrm{PpW}$ & Periproct length / Periproct width \\
\hline PBS & Peristome base shape (rect, rounded, trapezoidal and triangular) \\
\hline ASP & Apical system position (subcentral, lateral) \\
\hline PL / PW & Peristome length / Length of posterior side of peristome \\
\hline AIL / AIIIL & Ambulacrum I length / Ambulacrum III length \\
\hline MAW / PIW & Maximum ambulacral I width / Maximum width of the outer poriferous zone of petal I \\
\hline
\end{tabular}

Additionally, we randomly selected 62 other specimens of C. caribaearum and $R$. pacifica in order to have representatives from other localities and to consider all possible sizes; and to observe which characters yield significant information for species identification. Eleven traits (TWl, THl, PW, PL, AIL, AIIIL, MAW, PIW, PB, AFFP, AFTP) were measured three times each, using an electronic Vernier caliper. We also considered two qualitative data: the peristome base shape and apical system position. All measurements, qualitative data, and ratio abbreviations are detailed in Table 1 (Fig. 3).
The Pearson's Correlation Coefficient was used to identify the greatest number of significant correlations between the characters of the species $R$. pacifica and C. caribaearum. A distribution analysis was performed to analyze the shape of the peristome using CRAN R's factoextra and FactoMineR packages (Lê, Josse, \& Husson, 2008; R Core Team, 2019). To compare the average values between different measurements, a F-test was run to check that there were similar variances between the species; the results of these F-test were then used in t-tests to analyze whether there are specific differences. Normality of measurements was verified by 

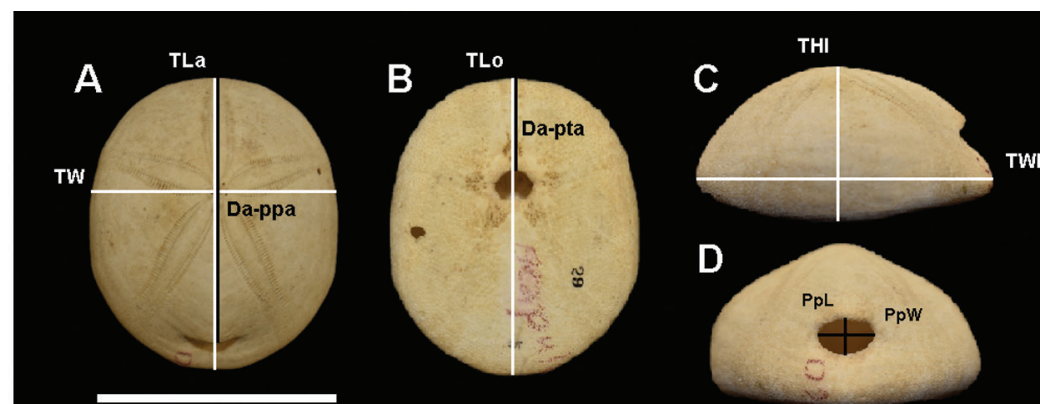

$2.5 \mathrm{~cm}$
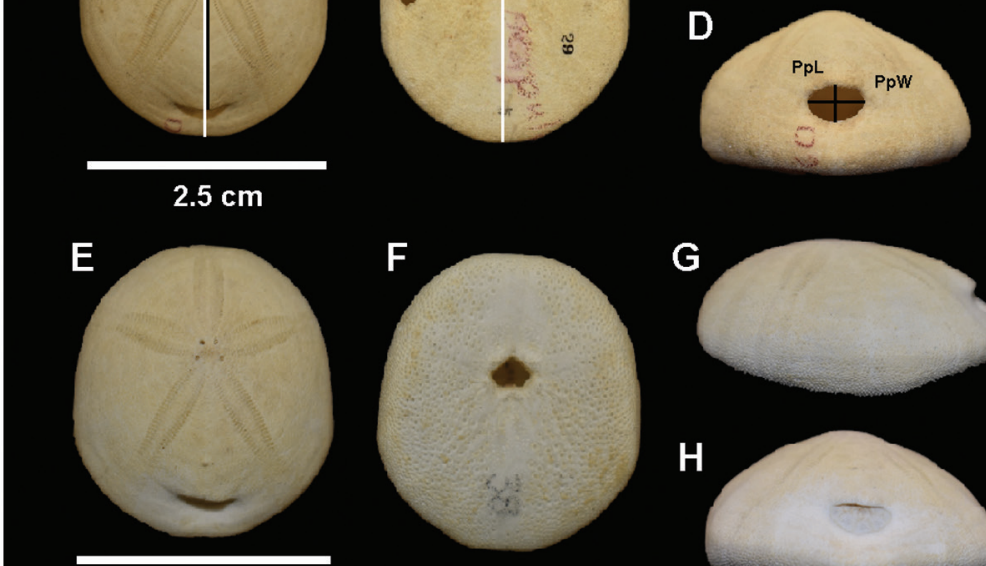

$3 \mathrm{~cm}$

Fig. 2. Rhyncholampas pacifica, ICML-UNAM 4.48.3. A. Aboral view. B. Oral view. C. Lateral view. D. Posterior view. Cassidulus caribaearum, ICML-UNAM 4.96.6. E. Aboral view. F. Oral view. G. Lateral view. H. Posterior view. Abbreviations refer to measurements defined in Table 1.

a Shapiro-Wilk test. We considered a test with a P-value $<0.05$ to be statistically significant.

To determine whether morphological groups exist within the analyzed species, a cluster analysis was carried out using Ward's minimum variance method. For this analysis, all the data from the specimens were used, and it was found that in both species the topology of the variables presents a similar ordering. To define the number of groups, the "Average Silhouette" method of the fviz_nbclust function, included as part of CRAN R's factoextra and FactoMineR packages (Lê et al., 2008; R Core Team, 2019) was used. This also allowed us to report the average values of the nonstandardized numerical variables by group, and to decide what separation distance to accept between different clusters.

Linked to the "Average Silhouette", k-mean analysis was performed to check if there were differences between the parameters in assigned groups. These analyses use the algorithm of
Hartigan and Wong (1979), assigning the variables to the fixed number of clusters.

\section{RESULTS}

Evaluation of test length and width: The linear regression (Fig. 4) showed a positive correlation between the variables Test length (aboral view) and Test width (at the level of the apical system). In this regard, R. pacifica reaches test length values of $51.5 \mathrm{~mm}$ and test width values of $42.6 \mathrm{~mm}$, whereas $C$. caribaearum does not exceed sizes of $22.9 \mathrm{~mm}$ and $19.4 \mathrm{~mm}$.

The eigenvalues for PC1 and PC2 were $1.21 \times 10^{-2}$ and $4.41 \times 10^{-3}$, whereas the percentages of variation were $59.3 \%$ and $21.6 \%$, respectively (Table 2); therefore, both $\mathrm{PC} 1$ and PC2 explain $80.9 \%$ of the cumulative variation of the data. The greatest eigenvalues for the first component occurred in THl/TWl and $\mathrm{PpL} / \mathrm{PpW}$, whereas in the second component, TLo/Da-pta and THl/TWl had the greatest 
A

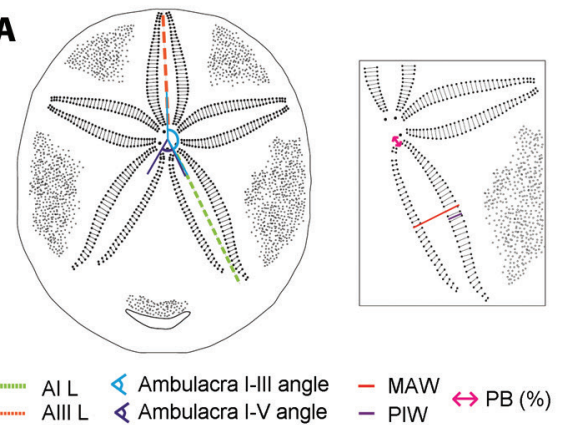

B

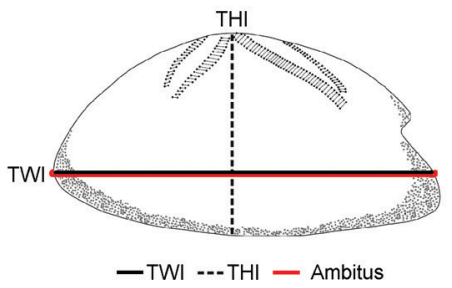

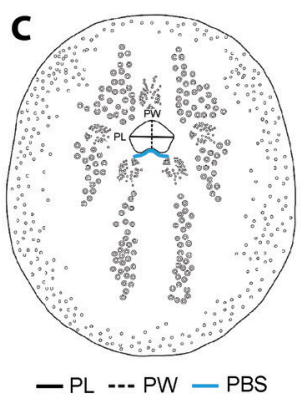

Fig. 3. Measurements used in the analysis. A. Aboral view and ambulacra I and II. B. Lateral view. C. Oral view. Abbreviations refer to measurements defined in Table 1.

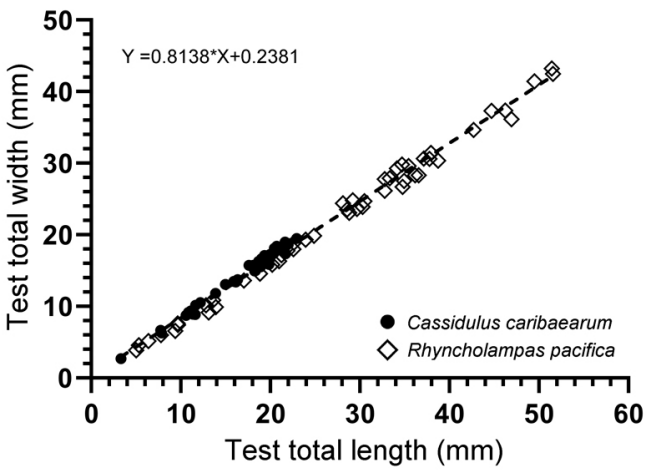

Fig 4. Linear regression of Test width (at the level of the apical system) vs Test length (aboral view) between Rhyncholampas pacifica and Cassidulus caribaearum.

eigenvalues. Considering both components, the THl/TWl (0.917) and TLo/Da-pta (0.925) were the two ratios which most contribute to the variation of the data, and separation of $R$. pacifica from C. caribaearum (Fig. 5).

Morphometric evaluation of other characters of taxonomic importance: In $R$. pacifica the highest Pearson's Correlations Coefficients were found between PW and PL, the lengths of ambulacra I and III; and MAW and PIW. Pearson's Correlation Coefficient values for this species ranged from 0.71 (test width (lateral view) vs. length of ambulacrum III; peristome length vs. peristome width and 0.99 (test width (lateral view) vs. lengths of ambulacra I/III and test height (lateral view)).
In the case of $C$. caribaearum, the strongest correlations had values of 0.60 (length of ambulacrum I vs. length of peristome) and 0.94 (test width (lateral view) vs. test height (lateral view)).

When analyzing the peristome base shape along with PW and PL, it was found that, in $R$. pacifica, it was wider and higher and the shape was triangular, while in $C$. caribaearum, the most predominant shape was round (Fig. 6).

In the specimens of $R$. pacifica, the largest correlation values ranged between 0.45 and 0.50 , while in $C$. caribaearum the correlation values were between 0.40 and 0.45 , which indicates a weak correlation (Fig. 7). When comparing the average values of the relationships between the lateral height and length for both species, a significant difference was found between the analyzed species ( $\mathrm{F}$ test for variances: $\mathrm{F}=0.5072$, g.1 . $_{\text {numerator }}=59$, g.l. denominator $_{\text {dit. }}$ $=58, \mathrm{P}=0.0104 ; \mathrm{t}$-test: $\mathrm{t}=6.2751$, d.f. $=$ 104.69, $\left.\mathrm{P}=8.022 \times 10^{-9}\right)$.

When linear regression models were used to compare the relationships of TW1 and PW with respect to other variables as possible intraspecific differentiators, no significant covariations were found. Covariates that were analyzed and showed values of lower significance were: 1) PBS (estimated parameter $=1.7148$, S.E. $=$ 1.2320, $\mathrm{t}=1.392, \mathrm{P}=0.17), 2) \mathrm{THl} / \mathrm{TWl}$ ratio, and 3) PBS (estimated parameter $=-4.3054$, S.E. $=2.7814, \mathrm{t}=1548, \mathrm{P}=0.128$ ). 


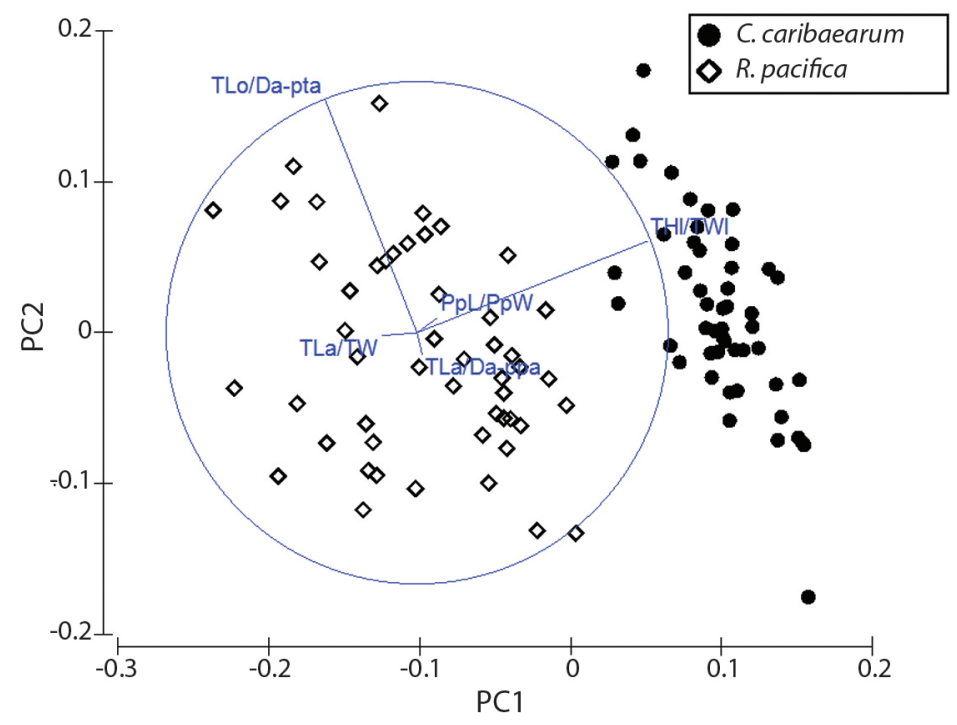

Fig. 5. Ordination (Principal Components Analysis) of Rhyncholampas pacifica and Cassidulus caribaearum. See Table 1 for acronyms.
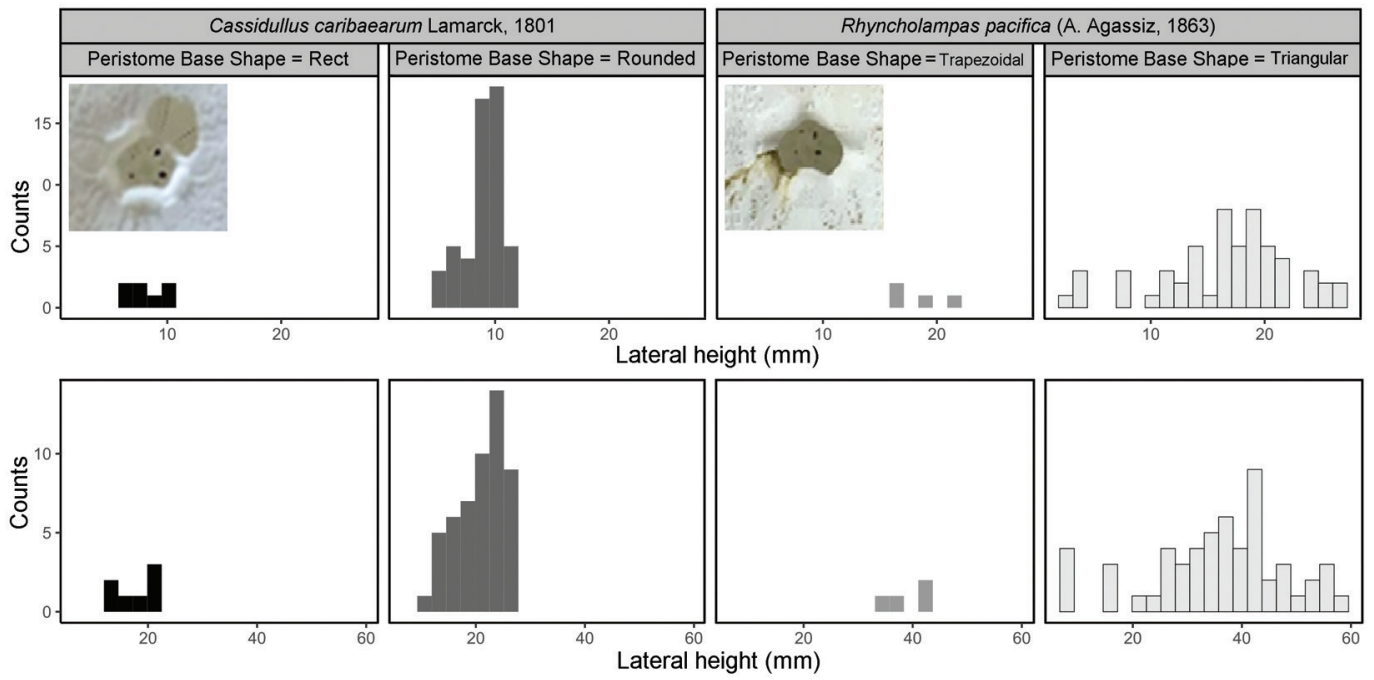

Fig. 6. Peristome base shape distribution analysis of Cassidulus caribaearum and Rhyncholampas pacifica.

Relationships between THl vs. TWl of R. pacifica tend to be slightly lower in the specimens with an ambitus between 21 and $40 \mathrm{~mm}$; this was also verified with a regression model (estimated parameter Ambitus $21-40$ $=-0.2008$, S.E. $=0.8861, \mathrm{t}=-2.266, \mathrm{P}=$ 0.0276). This observation should be tested further with a larger sample to determine if it occurs in a general way in the species. Cassidulus caribaearum specimens with larger ambitus perimeter sizes $(>40 \mathrm{~mm})$ tended to present a relationship between TWl and PW independent of the relationship between THl vs. TWl, while specimens of smaller size (up to $40 \mathrm{~mm}$ perimeter) tended to have a $\mathrm{PL} / \mathrm{PW}$ ratio that correlates positively with the relationship between 
TABLE 2

Eigenvalues (Principal Components Analysis) of Rhyncholampas pacifica and Cassidulus caribaearum

\begin{tabular}{|c|c|c|c|c|c|c|}
\hline Eigenvalues & Principal Component & Eigen-values & \multicolumn{2}{|c|}{ Explained variation (\%) } & \multicolumn{2}{|c|}{ Cumulative variation (\%) } \\
\hline & PC1 & $1.21 \times 10^{-2}$ & \multicolumn{2}{|c|}{59.3} & \multicolumn{2}{|c|}{59.3} \\
\hline & PC2 & $4.41 \times 10^{-3}$ & \multicolumn{2}{|c|}{21.6} & \multicolumn{2}{|c|}{80.9} \\
\hline & PC3 & $2.3 \times 10^{-3}$ & \multicolumn{2}{|c|}{11.3} & \multicolumn{2}{|c|}{92.2} \\
\hline & PC4 & $1.21 \times 10^{-3}$ & \multicolumn{2}{|c|}{5.9} & \multicolumn{2}{|c|}{98.1} \\
\hline & PC5 & $3.89 \times 10^{-4}$ & \multicolumn{2}{|c|}{1.9} & \multicolumn{2}{|c|}{100} \\
\hline \multirow[t]{6}{*}{ Eigenvectors } & Variable & PC1 & PC2 & PC3 & PC4 & PC5 \\
\hline & $\mathrm{TLa} / \mathrm{TW}$ & -0.138 & -0.011 & 0.212 & -0.224 & 0.941 \\
\hline & TLa / Da-ppa & 0.020 & -0.085 & 0.370 & -0.878 & -0.290 \\
\hline & TLo / Da-pta & -0.366 & 0.925 & 0.001 & -0.077 & -0.061 \\
\hline & TH1 / TWl & 0.197 & 0.364 & -0.053 & -0.081 & 0.132 \\
\hline & $\mathrm{PpL} / \mathrm{PpW}$ & 0.079 & 0.058 & 0.903 & 0.408 & -0.094 \\
\hline
\end{tabular}

TABLE 3

K-means (Silhoutte) cluster analysis in Cassidulus caribaearum (Dissimilar averages are marked in bold. Minimum and maximum averages are marked in black)

\begin{tabular}{|c|c|c|c|c|c|c|}
\hline \multirow{2}{*}{ Variable } & \multirow{2}{*}{$\begin{array}{l}\text { SW test } \\
\text { P-value }\end{array}$} & \multicolumn{4}{|c|}{ Centers (Average) } & \multirow{2}{*}{$\begin{array}{l}\text { ANOVA } \\
\text { P-value }\end{array}$} \\
\hline & & Group 1 & Group 2 & Group 3 & Group 4 & \\
\hline Lateral length $=T W l$ & 0.0579 & 16.155 & 24.484 & 22.567 & 24.532 & 0.162 \\
\hline Lateral height $=T H l$ & 0.0439 & 7.1400 & 10.315 & 9.6115 & 10.810 & 0.324 \\
\hline THl/TWl ratio & 0.0591 & 0.4424 & 0.4212 & 0.4280 & 0.4423 & 0.222 \\
\hline Peristome length $=P L$ & 0.4174 & 1.6975 & 2.2000 & 1.8321 & 2.1550 & 0.625 \\
\hline Peristome width $=P W$ & 0.0539 & 1.5550 & 2.0600 & 1.9029 & 1.9675 & 0.256 \\
\hline$P W / P L$ ratio & 0.0316 & 0.9349 & 0.9519 & 1.0691 & 0.9592 & 0.117 \\
\hline Ambulacral I length $=$ AIL & 0.3911 & 5.6587 & 9.1062 & 8.2250 & 9.5600 & 0.368 \\
\hline Ambulacral III length $=$ AIIIL & 0.8939 & 7.4375 & 11.629 & 10.205 & 12.212 & 0.696 \\
\hline AIL/AIIIL ratio & 0.1204 & 0.7714 & 0.8131 & 0.8173 & 0.7845 & 0.429 \\
\hline Ambulacral I-III angle & 0.1449 & 66.250 & 63.750 & 70.429 & 73.750 & 0.926 \\
\hline Ambulacral I-V angle & 0.0297 & 64.750 & 60.000 & 67.714 & 77.250 & 0.069 \\
\hline Max. ambulacral width $=$ MAW & 0.8554 & 1.8562 & 3.6925 & 2.5100 & 2.8100 & 0.345 \\
\hline $\begin{array}{l}\text { Maximum width of the outer poriferous zone } \\
\text { of petal } I=P I W\end{array}$ & 0.6090 & 0.4500 & 0.4837 & 0.4014 & 0.5750 & 0.015 \\
\hline MAW/PIW ratio & 0.0010 & 4.2321 & 5.9318 & 6.8442 & 4.9714 & 0.008 \\
\hline Size of group & & 8 & 8 & 14 & 4 & \\
\hline Within Sum of Squares & & 176.9432 & 246.7969 & 387.0671 & 66.1314 & \\
\hline Between_SS / Total_SS & & & 63.5 & $\%$ & & \\
\hline
\end{tabular}

THl vs. TWl (Fig. 7); however the increased ratios were not significant $(\mathrm{P}=0.170)$. In $R$. pacifica, some of the forms that had higher PL/ PW ratios also had elevated and triangular peristome base shapes. In addition, the specimens that had perimeters of the ambitus between 40 and $59 \mathrm{~mm}$ generally tended to present a lower $\mathrm{PL} / \mathrm{PW}$ ratio as the first of these relationships decreases (Table 3); there was also no significant correlation $(\mathrm{P}=0.0991)$.

To describe other morphometric features, we analyzed the distributions of the angle between the ambulacra I and V vs. the THI/ TWl ratio. In this case, we recognized two patterns: 1) The larger specimens of C. caribaearum (ambitus 59-78.1 mm) had larger 
angles and larger distances between ambulacra, from 59-79 $\mathrm{mm}$ long and more than $70^{\circ}$ (acute angle), with straight and rounded peristome base shape, and were independent from the test ratio compared with the rest of the sizes; and 2) In $R$. pacifica there was a relation between the variables: large specimen size (ambitus $45-69 \mathrm{~mm}$ ) tended to have ratio values from $0.45-0.50$, the angles were between 50 and $70^{\circ}$ (more acute than $C$. caribaearum) and the peristome was tall and triangular. These two patterns were noticeable in other clusters of morphological test variations. In terms of the general test morphology of $C$. caribaearum, the ambitus and the bulge were slightly ovoid and elongated, and dorsoventrally flattened, with low ambitus sizes between 21 and $78.91 \mathrm{~mm}$. We observed within the different groups and sizes low, intermediate and high ratios between the MAW and PIW, in combination with the lowest values of the distances between ambulacra, and that specimens had an ambitus of intermediate to large size. This suggests that $C$. caribaearum does not have specific variations between the different sizes; intermediate morphology may exist, meaning a continuous variability. Rhyncholampas pacifica, however, has a gibbous test and shows several kinds of variations; sizes (ambitus measurements) showed that the specimens with the largest perimeters of the ambitus had the lowest TH1, TWl, AIL, AIIIL, angle between ambulacra I and V and low relationships between the MAW and PIW, AIL and AIIIL measurements; conversely, the medium-sized specimens had the highest values of these features and the smallest sizes of the species (ambitus 1.92-21 mm) did not have a particular relation between them.

In the case of the angles between the ambulacra I and V, it was found that C. caribaearum tended to present values that range between 59 and $79 \mathrm{~mm}$ (average value $=66.76 \mathrm{~mm}$, S.D. $=4.0869 \mathrm{~mm}$ ), while for $R$. pacifica these values oscillated between 45 and $69 \mathrm{~mm}$ (average value $=59.8 \mathrm{~mm}$, S.D. $=5.6382$ ). Also, $C$. caribaearum tended to present rounded forms of the peristome base shape, and the forms that had larger ambitus also had angles between ambulacra I and V that were much greater than the rest of the specimens in the same species (above $70^{\circ}$ ); this was independent of their relationships between THl and TWl. Meanwhile, in $R$. pacifica the specimens had peristome base shape that are triangular, and the specimens with higher values of ambitus tended to present TH1/TW1 ratio values that were concentrated between 0.45 and $0.50 \mathrm{~mm}$ (Fig. 7).

In $R$. pacifica the organisms had a size range that can exceed $50 \mathrm{~mm}$ in length (largest specimen: $51.6 \mathrm{~mm}$ ) and $40 \mathrm{~mm}$ (largest specimen: $42.6 \mathrm{~mm}$ ) in width; in C. caribaearum the sizes did not exceed $25 \mathrm{~mm}$ in length (largest specimen: $22.9 \mathrm{~mm}$ ) and $20 \mathrm{~mm}$ in width (largest specimen: $19.4 \mathrm{~mm}$ ) (Table 3, Table 4).

For C. caribaearum, a first cluster includes the specimens with smaller ambitus combined with some specimens with ambitus up to 59 $\mathrm{mm}$ in perimeter, with a considerable number of specimens showing low ratios between MAW/PIW. A particular case for this variable is presented by a second group, where the specimens reach the highest ratios between MAW/ PIW in combination with the lowest values of PIW and whose specimens have ambitus of intermediate to high size, with some specimens being in the range of 59 to $91 \mathrm{~mm}$ in perimeter. A third group is formed by specimens in which the ratios between MAW/PIW generally have intermediate values, in combination with slightly low values for THl, TWL, AIL and MAW. The fourth group was represented by specimens with the highest average of ambulacral angles, in combination with slightly greater distance between PIW than in the other groups. The groups and average values of the analyzed measurements are shown in Fig. 8.

Two groups were observable for $R$. pacifica, the first of which includes the specimens with the largest perimeters of the ambitus with generally low measurements of THl, TWl, AIL, AIIIL, and angle between ambulacra I and V, these specimens also presented weak relationships between the MAW and PIW; and AIL and AIIIL. Some of these specimens also showed slightly large values for the PIW and the relationship between THl/TWl of the organism. 


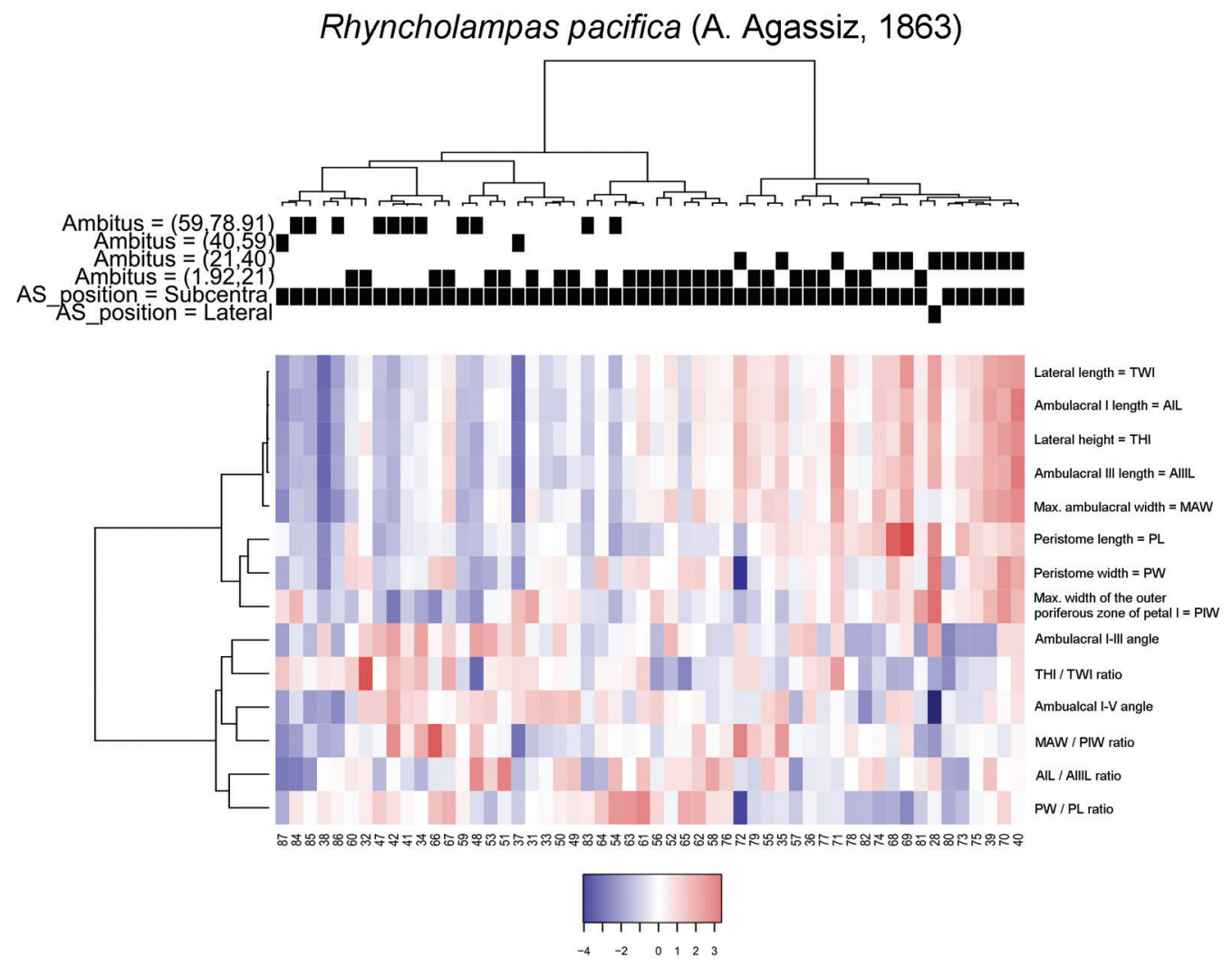

Fig. 7. Scatterplot of angle between ambulacra I and V vs. lateral height/lateral length ratio.

TABLE 4

K-means (Silhoutte) cluster analysis in Rhyncholampas pacifica (Dissimilar averages are marked in bold.

Minimum and maximum averages are marked in black)

\begin{tabular}{|c|c|c|c|c|}
\hline \multirow{2}{*}{ Variable } & \multirow{2}{*}{$\begin{array}{l}\text { S-W test } \\
\text { P-value }\end{array}$} & \multicolumn{2}{|c|}{ Centers (Average) } & \multirow{2}{*}{$\begin{array}{l}\text { Welch t-test } \\
\text { P-value }\end{array}$} \\
\hline & & Group 1 & Group 2 & \\
\hline Lateral length $=T W l$ & 0.7440 & 30.658 & 45.4996 & $3.89 \times 10^{-12}$ \\
\hline Lateral heigh $=T H l$ & 0.7038 & 14.478 & 21.0444 & $8.12 \times 10^{-11}$ \\
\hline THl/TWl ratio & 0.6036 & 0.4726 & 0.4626 & 0.118 \\
\hline Peristome length $=P L$ & 0.0021 & 2.4559 & 3.4030 & $1.49 \times 10^{-5}$ \\
\hline Peristome width $=P W$ & 0.4988 & 2.9733 & 3.5485 & 0.008 \\
\hline$P W / P L$ ratio & 0.4730 & 1.2277 & 1.0724 & 0.041 \\
\hline Ambulacral I length $=$ AIL & 0.9538 & 11.709 & 18.523 & $1.54 \times 10^{-11}$ \\
\hline Ambulacral III length $=$ AIIIL & 0.9589 & 13.082 & 20.309 & $2.58 \times 10^{-11}$ \\
\hline AIL/AIIIL ratio & 0.8015 & 0.8943 & 0.9132 & 0.254 \\
\hline Ambulacral I-III angle & 0.0002 & 72.296 & 69.815 & 0.240 \\
\hline Ambulacral I-V angle & 0.1038 & 62.074 & 59.741 & 0.064 \\
\hline Maximum ambulacral width $=$ MAW & 0.8296 & 3.2211 & 4.6459 & $1.66 \times 10^{-9}$ \\
\hline Maximum width of the outer poriferous zone of petal $I=P I W$ & 0.9724 & 0.5644 & 0.6681 & $\mathbf{0 . 0 3 1}$ \\
\hline MAW/PIW ratio & 0.0317 & 6.1316 & 7.4129 & 0.026 \\
\hline Size of group & & 27 & 27 & \\
\hline Within Sum of Squares & & 3905.777 & 3869.790 & \\
\hline Between_SS / Total_SS & & 39.7 & $\%$ & \\
\hline
\end{tabular}



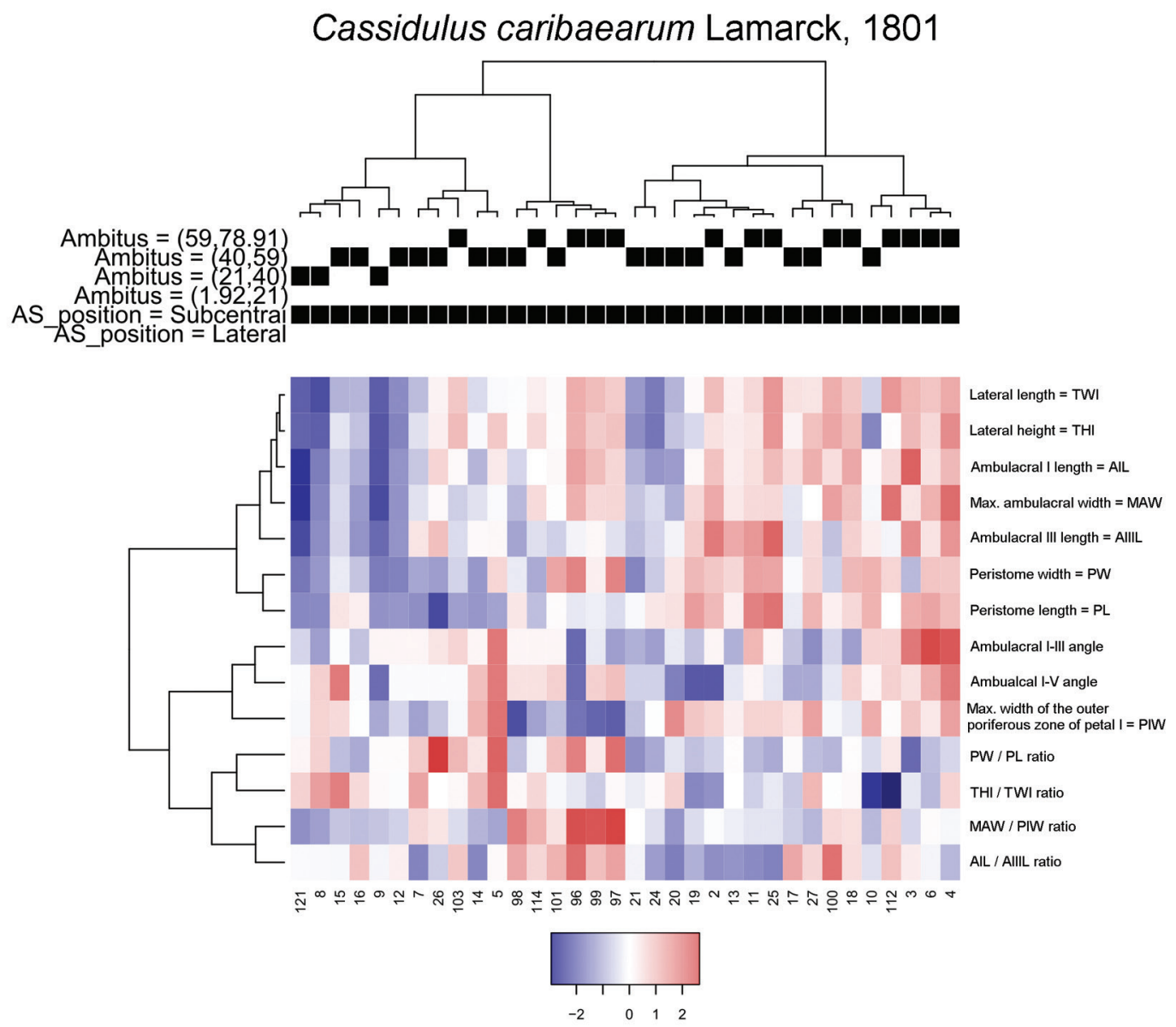

Fig. 8. Heatmap coupled to cluster diagrams for Cassidulus caribaearum. Centered variables were used for the construction of the heatmap.

The second group is composed by specimens with small to medium sized ambitus, in this case the specimens of greater THl and TWl, with one of them showing even the largest sizes on the PW, another with the lowest value of the angle between I and V ambulacra and one more presenting the lowest values of PW that also corresponds to the lowest ratio between $\mathrm{PL} / \mathrm{PW}$. The groups and average values of the analyzed measurements are shown in Fig. 9.

\section{DISCUSSION}

Cassidulus caribaearum and $R$. pacifica have been considered very closely related species, but Souto et al. (2019) proved that the genera Rhyncholampas and Cassidulus have been separated for more than 60 million years. However, the interspecific morphological differences between these two extant species are still being analyzed.

Souto et al. (2019) studied the intraspecific variations of the morphological features of $C$. caribaearum and $R$. pacifica, tests noticed a great variation in the number of phyllopores plates and of occluded plates in all phyllodes, and in the number of additional pore pairs in the unequal (paired) petals. Regarding test length and width (lateral view), C. caribaearum is a small to medium-sized species (neotype test measurements from Souto \& 


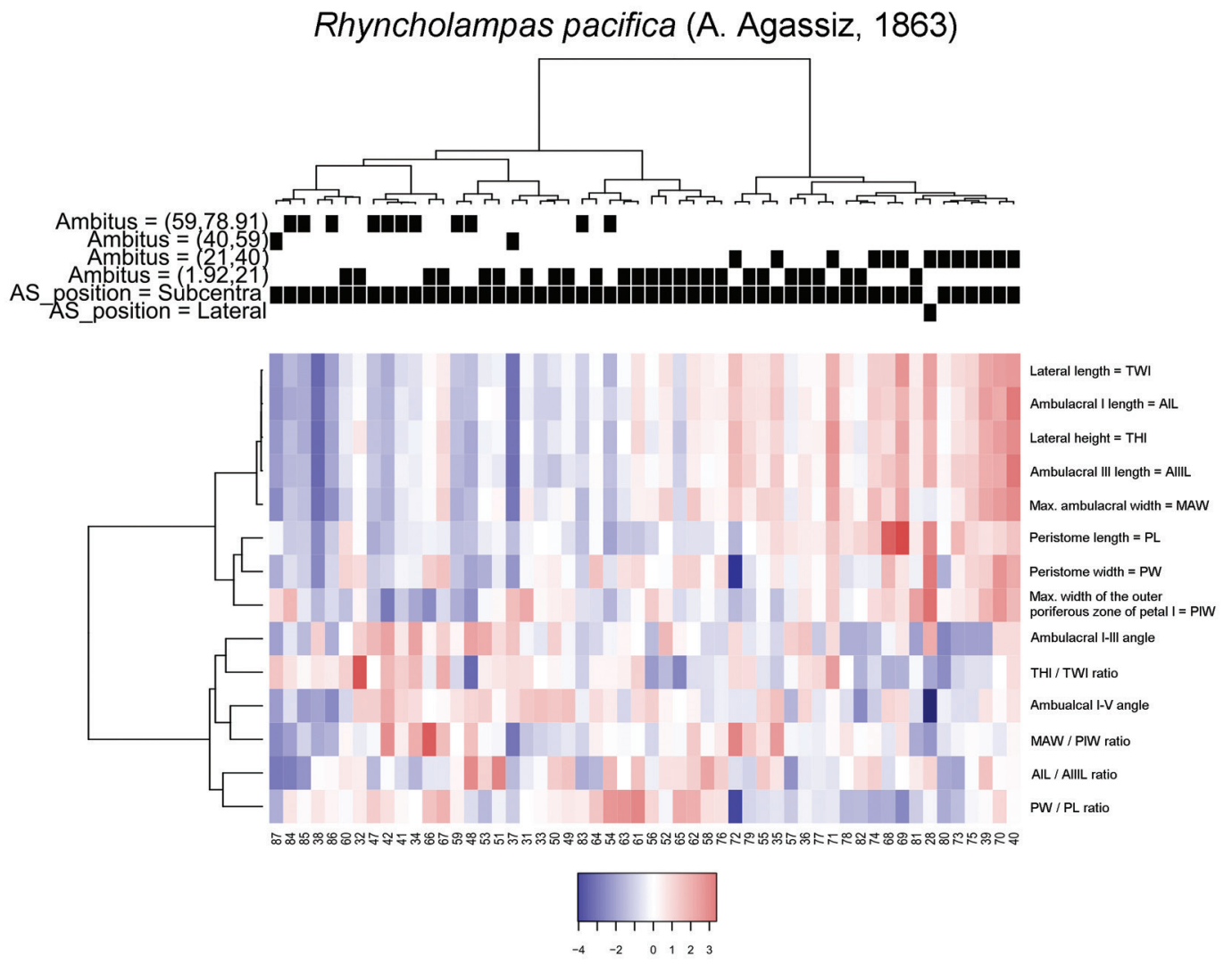

Fig. 9. Heatmap coupled to cluster diagrams for Rhyncholampas pacifica.

Centered variables are used for the construction of the heatmap.

Martins, 2018: total length $26.68 \mathrm{~mm}$, total width $22.65 \mathrm{~mm}$, and total height $11.71 \mathrm{~mm}$ ) with oval test; the total width is approximately $85 \%$ of the total length. The lateral edges are straight with round margins; the greatest height is at the apical disc; it has a triangular transverse section and a concave oral region (Souto \& Martins, 2018). Schultz (2017) mentioned that length of $C$. caribaearum scarcely reaches $25 \mathrm{~mm}$. In this study we found that C. caribaearum from the Mexican Caribbean Sea (50 specimens from Punta Nizuc to Punta Maroma, Quintana Roo, Mexico) does not exceed sizes of $22.9 \mathrm{~mm}$ length and $19.4 \mathrm{~mm}$ width; individual variation ranges of test length are from 3.312-22.959 mm and width are from 2.708$18.995 \mathrm{~mm}$. The genus Rhyncholampas have been described as small to large of varying test shape with maximum length up to $70 \mathrm{~mm}$ in the living species (Agassiz, 1869; Schultz, 2017; Souto et al., 2019). This analysis showed specimens of $R$. pacifica from the Mexican Pacific (50 specimens from Punta Barron, Sinaloa to Acapulco, Guerrero, Mexico) clearly reach test length values of $51.5 \mathrm{~mm}$ and test width values of $42.6 \mathrm{~mm}$; individual variation ranges of test length are from $5.01-51.59 \mathrm{~mm}$ and width are from 4.549-43.222 $\mathrm{mm}$.

Martínez-Melo (2008) stated that test height, peristome length and distance from the peristome to the anterior edge of the test are the most significant measurements that separate $C$. caribaearum from $R$. pacifica, supporting that test dimensions are different between both species. Here we also used the test height and distance from the peristome to the anterior edge 
of the test, here referred as Da-pta, as variables of the ratios TH1/TWI and TLo/Da-pta which primarily contributes to the discrimination of $C$. caribaearum from $R$. pacifica in the PCA analysis. Therefore, we confirm that these measurements, as variables of such ratios, allow us to distinguish between both species. Martínez-Melo (2008) also mentioned that $R$. pacifica had a taller test and longer peristome than $C$. caribaearum. In this regard, we found test height values of 6.919 to $15.67 \mathrm{~mm}$ for $R$. pacifica, and 5.976 to $6.088 \mathrm{~mm}$ for C. caribaearum, agreeing with $R$. pacifica having a taller test. In addition, Martínez-Melo (2008) mentioned that $C$. caribaearum had a lower distance from the peristome to the anterior edge of the test. We confirm her statement because the Da-pta values for $C$. caribaearum range from 1.354 to $8.235 \mathrm{~mm}$, and 1.55 to 15.789 for $R$. pacifica. The author explained these lower values of Da-pta for C. caribaearum as a result of the higher growth of its skeleton.

When analyzing the intraspecific variation in the test length and width in proportion, we found that $R$. pacifica had 1:1.047, which means it is slightly longer than it is wide; in C. caribaearum the proportion is $1: 1.185$, also being longer than wide. From the measurements of TWl, THl, AL, PL, PW, AIL, AIIIL, MAW, PIW, PB, AFFP, TLa/TW, TLa/Da-ppa, TLo/Da-pta, THl/TL1, PpL/PpW, A, PBS, PS, ASP, PL/PW, AIL/AIIIL, and MAW/PIW, we conclude that the small specimens developed a more inflated form during their juvenile stage, with longer and wider ambulacra; then, when they reach the adult form, they developed a more flat test gibbosity inside their own triangular, inflated shape, unlike C. caribaearum which keep almost the same shape during their transition from small to large size (3.313$22.959 \mathrm{~mm}$ ).

Regarding the variations of the peristome, although in both species the relationship between the measurements of the top of the test and the shape of the base of the peristome is not very clear, it is possible to identify the variation of the base of the peristome between species; in C. caribaearum, the smaller specimens (lateral height and lateral width) have a straight shape, while in larger specimens the base is rounded. We observed a similar behavior in $R$. pacifica, since in the smaller specimens the base of the peristome is triangular and tall; on the other hand, in the larger specimens the base is perceived as completely triangular. Souto and Martins (2018) assigned a neotype of $C$. caribaearum (with measurements of test length $=26.68 \mathrm{~mm}$ and test height $=22.65 \mathrm{~mm}$ ) mentioning that the shape of the peristome is pentagonal; this probably indicates that the growth of the test is related with the change in the shape of the peristome base and, consequently, of the complete shape of the peristome.

Rhyncholampas pacifica shows a test with slender form, which corresponds to a longer and pointier interambulacral basicoronal plate $\mathrm{V}$ towards the peristome while in $C$. caribaearum the test shape is broader with a flattened plate. As suggested by Saitoh and Kanazawa (2012), slender forms tend to dig deeper into the substratum whereas robust forms dig shallow; the anterior suggests that $R$. pacifica is more adapted to dig deeper in certain types of substratum (e.g. sandy) than $C$. caribaearum.

We confirm that $R$. pacifica has a taller test than $C$. caribaearum, while the latter has a lower distance from the peristome to the anterior edge of the test. We also recognize two intraspecific patterns between the ambulacra length and angles, and the peristome shape, for each living species.

In sum, it is demonstrated that morphometric data of the tests and peristome are useful to address taxonomical issues on recent cassiduloids, suggesting that more morphometric studies including other species could be carried out. Moreover, new morphometric analysis of the species studied here adding specimens from the rest of their geographic distribution range would be useful to compare these results.

Ethical statement: authors declare that they all agree with this publication and made significant contributions; that there is no conflict of interest of any kind; and that we 
followed all pertinent ethical and legal procedures and requirements. All financial sources are fully and clearly stated in the acknowledgements section. A signed document has been filed in the journal archives.

\section{ACKNOWLEDGMENTS}

We are thankful to Camilla Souto (Smithsonian Institution, Washington D.C., USA), Sergio A. Martínez (Universidad de la República de Uruguay, Montevideo, Uruguay) and an anonymous reviewer for providing feedback that improved the quality of the manuscript. Thanks to Ma. Esther Diupotex Chong and Alicia Durán González (ICML, UNAM) for their technical support at the Colección Nacional de Equinodermos (ICML, UNAM). We would like to thank M.G. Lovegrove for his valuable comments on the manuscript's English. CACV (scholarship holder 666781) thanks the Consejo Nacional de Ciencia y Tecnología (CONACyT) for his doctorate grant 722925. DGAPA-UNAM, PAPIIT Project No. IN108717 "Tasas de evolución y paleobiogeografia de la familia Cassidulidae (Echinodermata: Echinoidea)".

\section{RESUMEN}

\section{Variabilidad morfológica de especies recientes del orden Cassiduloida (Echinodermata: Echinoidea) de México}

Introducción: En México, hay dos especies vivientes registradas de Cassiduloida: Cassidulus caribaearum y Rhyncholampas pacifica. La mayoría de los estudios taxonómicos sobre casiduloides han utilizado morfología externa, pedicelarios y caracteres morfométricos; sin embargo, la variación intraespecífica de caracteres cuantitativos y cualitativos ha sido poco evaluada. Objetivo: Comparar la morfología básica de $R$. pacifica y $C$. caribaearum. Métodos: Examinamos un total de 2158 especímenes de $R$. pacifica y C. caribaearum, seleccionando 50 para evaluar la forma y el tamaño con regresión lineal y análisis de componentes principales. Seleccionamos 62 especímenes adicionales por especie para identificar correlaciones significativas de caracteres y grupos morfológicos dentro de las especies. Resultados: Existe una relación directa entre la longitud de la testa y el ancho de la testa. La Altura de la testa / Anchura de la testa y la Longitud total (vista oral)
/ Distancia desde el ambitus hasta el ápice del peristoma, son las dos proporciones principales para distinguir ambas especies. C. caribaearum está más comprimido dorsoventralmente y tiene una base del peristoma redonda; versus $R$. pacifica que tenía una alta y triangular. Hay cuatro grupos morfológicos de C. caribaearum y dos grupos de $R$. pacifica. Conclusiones: Estas dos especies se pueden distinguir con caracteres morfológicos confiables, en los que la forma del peristoma sugiere que $R$. pacifica está más adaptada para excavar más profundamente en ciertos tipos de sustratos.

Palabras clave: Neognathostomata; Cassiduloida; morfometría; México.

\section{REFERENCES}

Agassiz, A. (1869). Preliminary report on the Echini and star-fishes dredged in deep water between Cuba and the Florida Reef, by L.F. de Pourtales, Assist. U.S. Coast Survey. Bulletin of the Museum of Comparative Zoölogy at Harvard College, 1, 253-308.

Agassiz, A. (1872). Revision of the echini. Memoirs of the Museum of Comparative Zoology, 3, 383-762.

Boivin, S., Saucède, T., Laffont, R., Steimetz, E., \& Neige, P. (2018). Diversification rates indicate an early role of adaptive radiations at the origin of modern echinoid fauna. PLoS ONE, 13(4), e0194575.

Borrero-Pérez, G.H., Benavides-Serrato, M., \& DiazSanchez, C.M. (2012). Equinodermos del Caribe colombiano II: Echinoidea y Holothuroidea. Santa Marta, Colombia: Serie de Publicaciones Especiales de Invemar No. 30.

Buitrón-Sánchez, B.E., Solís-Marín, F.A., Conejeros-Vargas, C.A., \& Caballero-Ochoa, A.A. (2019). Equinodermos de las familias Echinolampadidae Gray, 1851 y Cassidulidae L. Agassiz y Desor, 1847 fósiles y recientes de México: estudio comparativo con base en macro y microestructuras. Paleontología Mexicana, $8(1), 51-63$.

Caballero-Ochoa, A.A., Martínez-Melo, A., ConejerosVargas, C.A., Solís-Marín, F.A., \& Laguarda-Figueras, A. (2017). Diversidad, patrones de distribución y "hotspots" de los equinoideos irregulares (Echinoidea: Irregularia) de México. Revista Biología Tropical, 65(1), S42-S59.

Carter, B.D., \& Beisel, T.H. (1987). “Cassidulus” trojanus belongs in the genus Eurhodia (Echinoidea) based upon new criteria. Journal of Paleontology, 61(5), 1080-1083.

Ciampaglio, C.N., \& D’Orazio, A.E. (2007). Heterochrony within the cassiduloid echinoids from the Castle Hayne Limestone of southeastern North Carolina. Historical Biology: An International Journal of Paleobiology, 19(4), 301-313. 
Clark, H.L. (1925). Marine Zoology of Tropical Central Pacific: Echinoderms other than sea-stars. Bulletin of the Bernice Pauahi Bishop Museum, 27, 89-111.

Gladfelter, W.B. (1978). General ecology of the cassiduloid urchin Cassidulus caribbearum. Marine Biology, 47, 149-160.

Hartigan, J.A., \& Wong, M.A. (1979). Algorithm AS 136: A K-means clustering algorithm. Journal of the Royal Statistical Society, Series C, Applied Statistics, 28(1), 100-108.

Kier, P.M. (1962). Revision of the cassiduloid echinoids. Smithsonian Miscellaneous Collections, 144(3), $1-262$.

Kier, P.M. (1974). Evolutionary trends and their functional significance in the post-Paleozoic echinoids. Journal of Paleontology, 48(S5), 1-95.

Kier, P.M. (1975). The echinoids of Carrie Bow Cay, Belize. Smithsonian Contributions to Zoology, 206, 1-45.

Lawrence, J.M., \& Cobb, J. (2017). Validation of Astropecten jarli Madsen, 1950 and implications for A. cingulatus Sladen, 1883 (Paxillosida: Astropectinidae). Zootaxa, 4269(1), 101-114.

Lê, S., Josse, J., \& Husson, F. (2008). FactoMineR: An R Package for Multivariate Analysis. Journal of Statistical Software, 25(1), 1-18.

MacLeod, N. (2017). Morphometrics: History, development methods and prospects. Zoological Systematics, 42(1), 4-33.

Martínez-Melo, A. (2008). Relación heterocrónica entre Rhyncholampas pacificus (A. Agassiz, 1863) y Cassidulus caribaearum Lamarck, 1801. (Master's thesis). Universidad Nacional Autonoma de Mexico, Mexico City, Mexico.

Martínez-Melo, A., De Luna, E., \& Buitrón-Sánchez, B.E. (2017). Morfometría de los equinoideos de la familia Cassidulidae (Echinoidea: Cassiduloida). Revista de Biología Tropical, 65(1), S233-S243.

McKinney, M.L. (1984). Allometry and heterochrony in an Eocene echinoid lineage: morphological change as by-product of size selection. Paleobiology, 10(4), 407-419.

McKinney, M.L. (1986). Ecological causation of heterochrony: a test and implications for evolutionary theory. Paleobiology, 12(3), 282-289.

McNamara, K., Pawson, D., Miskelly, A., \& Byrne, M. (2017). Class Echinoidea. In M. Byrne, \& T.D O'Hara (Eds.), Australian Echinoderms: Biology, Ecology and Evolution (pp. 351-445). Clayton South: CSIRO Publishing.
Mooi, R. (1990). Living cassiduloids (Echinodermata: Echinoidea): a key and annotated list. Proceedings of the Biological Society of Washington, 103(1), 63-85.

Ocakoglu, G., \& Ercan, I. (2013). Traditional and modern morphometrics: review. Turkiye Klinikleri Journal of Biostatistics, 5(1), 37-41.

R Core Team. (2019). R: A Language and Environment for Statistical Computing. R Foundation for Statistical Computing. Vienna, Austria. Retrieved from http:// www.r-project.org

Remagnino, P., Mayo, S., Wilkin, P., Cope, J., \& Kirkup, D. (2016). Morphometrics: a brief review. In P. Remagnino, S. Mayo, P. Wilkin, J. Cope, \& D. Kirkup, D. (Eds.), Computational Botany (pp. 11-32). Germany: Springer-Verlag Berlin Heidelberg.

Saitoh, M., \& Kanazawa, K. (2012). Adaptative morphology for living in shallow water environments in spatangoid echinoids. Zoosymposia, 7, 255-265.

Schultz, H.A.G. (2017). Echinoidea. Vol. 2, Echinoidea with bilateral symmetry. Irregularia. In A. SchmidtRhaesa (Ed.), Handbook of Zoology-Handbuch der Zoologie (pp. 1-359). Hemdingen, Germany: De Gruyter.

Solís-Marín, F.A., Alvarado, J.J., Abreu-Pérez, M., Aguilera, O., Alió, J., Bacallado-Aránega, J.J., Barraza, E., ... Williams, S.M. (2013). Appendix: A.1 Taxonomic list of the Echinoderms of the Pacific coast of Latin America. In J.J. Alvarado \& F.A. Solís-Marín (Ed.), Echinoderm Research and Diversity in Latin America (pp. 544-601). Berlin, Heidelberg: Springer.

Solís-Marín, F.A., Caballero-Ochoa, A.A., LaguardaFigueras, A., \& Durán-González, A. (2017). Catálogo de Autoridades Taxonómicas de los Equinodermos de México. Ciudad de México, México: Instituto de Ciencias del Mar y Limnología (ICML), Universidad Nacional Autónoma de México (UNAM). Informe final, SNIB-CONABIO, proyecto No. Z002.

Souto, C., \& Martins, L. (2018). Synchrotron micro-CT scanning leads to the discovery of a new genus of morphologically conserved echinoid (Echinodermata: Cassiduloida). Zootaxa, 4457(1), 70-92.

Souto, C., Mooi, R., Martins, L., Menegola, C., \& Marshall, C.R. (2019). Homoplasy and extinction: the phylogeny of cassidulid echinoids (Echinodermata). Zoological Journal of the Linnean Society, 187, 622-660.

Suter, S.J. (1988). The decline of the cassiduloids: merely bad luck? Victoria: Proceedings of the International Echinoderms Conference. 